AJChE 2014, Vol. 14, No. 1, 59 - 75

\title{
Experimental Study on Hydrocracking Process of Ashuton Hydrocarbon Based on the Aromatic, and Waxy Residue Based on Paraffinic, by using Pt/Pd and Y-Alumina Catalyst in a Fixed Bed Reactor
}

\author{
Bardi Murachman *1 \\ Deendarlianto ${ }^{2}$ \\ Nissaraly. H.F. ${ }^{1}$ \\ Wakhid Hasyim ${ }^{1}$ \\ 1 Laboratory of Petroleum, Gas, and Coal Technologies, Department of Chemical \\ Engineering, Faculty of Engineering, Gadjah Mada University, Jalan Grafika No. 2 \\ Yogyakarta 55281, Indonesia. \\ 2 Department of Mechanical and Industrial Engineering, Faculty of Engineering, Gadjah \\ Mada University, Jalan Grafika No. 2 Yogyakarta 55281, Indonesia. \\ *e-mail : bmurachman@chemeng.ugm.ac.id
}

The studies on the hydrocracking process to obtain the fuel by cracking of the carbon chain from the hydrocarbon compound both in the form of gas and liquid fuels have been carried-out massively by researchers over three decade. In the present experimental study, heavy hydrocarbon represented by asphaltic base materials (named as Extracted Asbuton) and paraffinic (waxy residue from Cepu oil refinery) were used as the object of the study; by observing the differences of the reaction mechanisms and the results that can be obtained. Here the operational conditions such as pressure, temperature, and time as well as the kinds of catalyst were considered as the main parameters.

The experiments were carried-out under the similar operating condition such as temperature around $350-500^{\circ} \mathrm{C}$, pressure around 5 up to 15 atmospheres, and evaporation time was $(1-3)$ hours. As a result, it was obtained (a) the higher the temperature, pressure, and heating time, the higher hydrocracking conversion both of hydrocarbons, (b) reaction mechanism of hydrocracking by using asphalt extract as the material follows the Model 3 of the present work, in which asphalt vapor was trapped in catalyst surface, meanwhile the waxy residue followed the Model 1, (c) under the same condition, the conversion of asphalt extract was smaller than waxy residue, and (d) the conversion of asphalt extract using Pt/Pd catalyst was higher than $\gamma$-Alumina catalyst.

Keywords : Asbuton, Waxy Residue, Hydrocracking, Reaction Mechanisms. 
60 Experimental Study on Hydrocracking Process of Asbuton Hydrocarbon, Based on the Aromatic, and Waxy Residue, Based on Paraffinic, by using Pt/Pd Catalyst and $\mathrm{y}$-Alumina in a Fixed Bed Reactor

\section{INTRODUCTION}

Recently, the process of hydrocracking has massively became the object of the study due to energy crisis around the world. The oil reserves in Indonesia are less than 50 billion barrels. However the effective reserves are only 1.6 billion barrels. From the economic energy calculation, by the improvement of energy need around $5-10 \%$, the effective reserves of fossil oil will run out in several upcoming years, if there is no extensification, diversification and intensification in the aspect of energy.

A lot of efforts have been performed to solve these problems. Those are the conversion of the petroleum weight fraction or other alternative materials becoming fuel fractions, such as kerosene, gasoline, and diesel fuel, whereas these materials are extensively used for daily needs. In the case of the petroleum, there are some kinds of heavy fraction of oil that have also been converted, such as heavy petroleum residue, burning oil, waxy residue, and asphalt.

The other materials that are not from the area of oil refineries but have not been applied commercially are natural asphalt (Asbuton, Trinidad Asphalt), biomass, vegetable/animal oil (palm oil, castor oil, animal fat), etc.

Asbuton is a kind of rock or soil originally from Buton Island of Indonesia. From several locations, it contains around $10 \%$ until $40 \%$ of natural asphalt and the other natural minerals such as iron, alumina, silica, etc (Sarifudin, 2004). Asphalt reserve in Buton Island is around 650 million tons It can be found only 1.5 meter under the soil surface. The composition of the Buton asphalt and the result of extraction test is presented in Table 1.

Buton asphalt can be separated from

Table 1. The Composition and Buton Asphalt Extraction Test (Abraham, 2007)

\begin{tabular}{lccc}
\hline & Kabungka & Lawele & Waisiu \\
\hline Raw Asphalt : & & & \\
Water & $1.5 \%$ & $2 \%$ & $1.5 \%$ \\
Asphalt & $17-39 \%$ & $25-35 \%$ & $35-37 \%$ \\
Organic Material & $0.2-1 \%$ & $0.5-2 \%$ & $0.2-1 \%$ \\
Mineral Material & $58-61 \%$ & $65-75 \%$ & $61-63 \%$ \\
Asphalt Extract : & & & \\
Sp. Gr. in $77^{\circ} \mathrm{F}$ & $1.09-1.12$ & 1.06 & 1.09 \\
Penetration in $77^{\circ} \mathrm{F}$ & $6-18$ & 73 & 10 \\
Fusing-point $\left(\mathrm{R} \mathrm{\&} \mathrm{B)}{ }^{\circ} \mathrm{C}\right.$ & $61-69$ & 47 & 24 \\
Ductility in $77^{\circ} \mathrm{C}$ & $12-110$ & 110 & 32 \\
Insol. in . Nafta $\left(88^{\circ} \mathrm{C}\right)$ & $23.7-29 \%$ & 25.7 & $25.9 \%$ \\
\hline
\end{tabular}

\section{Extraction Test}

$\begin{array}{lc}\text { Asphalten } & 23-30 \% \\ \text { Sulfure } & 6-7 \% \\ \text { Acide level } & 6,2 \\ \text { Saponification Value } & 14\end{array}$


their rocks by the extraction process. The researches use some solvents like : $\mathrm{TCE}$, CCl4, naphta, hexane, and condensate. The derivative products of extracted buton asphalt can be used as reservoir partition material, vehicle layer material, ink material, paint material, bricket, and fuel.

The hydrocracking process is the most common method to get fuel from some kind of material, include asphalt and heavy fraction of petroleum. Hydrocracking can be defined as a cracking process of hydrocarbon compound catalytically by injecting hydrogen under a high temperature and high pressure to obtain some products. The main reaction in hydrocracking process is the reaction of cracking chain among $\mathrm{C}-\mathrm{C}$ atoms that can be divided into three parts. Those are paraffin hydrocracking, hydro-dealcilation, and hydro-decyclisation reactions. Hydrocracking process is used for feed with high content of aromatic compound that cannot be processed easily by using a conventional catalytic cracking process (Hatch \& Matar, 2000).

Catalytic cracking has some benefit in comparing to thermal cracking. Those are: 1) improving gasoline productivity and forming the components of the hydrocarbon compound that has anti knocking character, 2) It can obtain a high $C_{3}$ and $C_{4}$ (Hatch \& Matar, 2000), The classification of the catalytic cracking reaction in several hydrocarbon is shown in Table 2.

The different kinds of raw materials, catalysts, and operating condition usually provide different results. This can be happened because of the different

Table 2. Catalytic Cracking Reaction Based on Hydrocarbon Classes (Abdul H. and Kharim, 2010)

\begin{tabular}{|c|c|c|}
\hline Hydrocarbon Classes & Reaction Principles & Result \\
\hline $\mathrm{n}$-Paraffins and isoparaffins & $\begin{array}{l}\text { Hydrokarbon releasing in } \\
\text { several different spots, } \\
\text { releasing in the edge of } \mathrm{C} \text { - } \\
\mathrm{C} \text { bond does not generally } \\
\text { happen }\end{array}$ & $\begin{array}{l}\text { Paraffin with branches } \\
\text { bond and olefin with ot } \\
\text { less than } 3 \text { carbon atoms, } \\
\text { a small amount of } \\
\text { methane. }\end{array}$ \\
\hline Naphthene & $\begin{array}{l}\text { Releasing /cutting ring and } \\
\text { branch bond }\end{array}$ & $\begin{array}{l}\text { Paraffin and olefin, a } \\
\text { small amount of } \\
\text { aromatic compound. }\end{array}$ \\
\hline Naphtheno-aromatic compound & $\begin{array}{l}\text { Opening naptenic ring, } \\
\text { extrication branch bond } \\
\text { from aromatic ring. }\end{array}$ & $\begin{array}{l}\text { Paraffin compound, } \\
\text { olefin and aromatic. }\end{array}$ \\
\hline $\begin{array}{l}\text { Aromatic compound without } \\
\text { braches bond }\end{array}$ & Difficult & Carbon ( coke) \\
\hline $\begin{array}{l}\text { Aromatic compound with branches } \\
\text { bond }\end{array}$ & $\begin{array}{l}\text { Releasing of branch bond } \\
\text { from aromatic ring }\end{array}$ & $\begin{array}{l}\text { Olefin compound and } \\
\text { aromatic. }\end{array}$ \\
\hline Olefin & $\begin{array}{l}\text { Cutting hydrocarbon bond } \\
\text { in several spots. }\end{array}$ & $\begin{array}{l}\text { Branches olefin } \\
\text { compound, a small } \\
\text { amount of paraffin } \\
\text { compound. }\end{array}$ \\
\hline
\end{tabular}




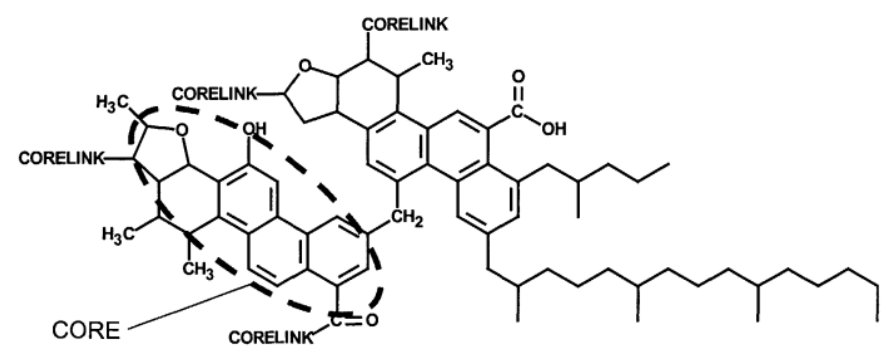

(a)

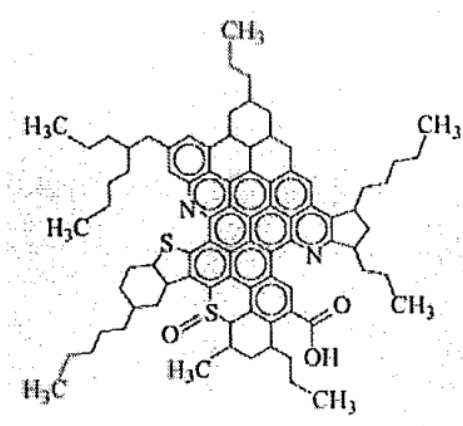

(b)
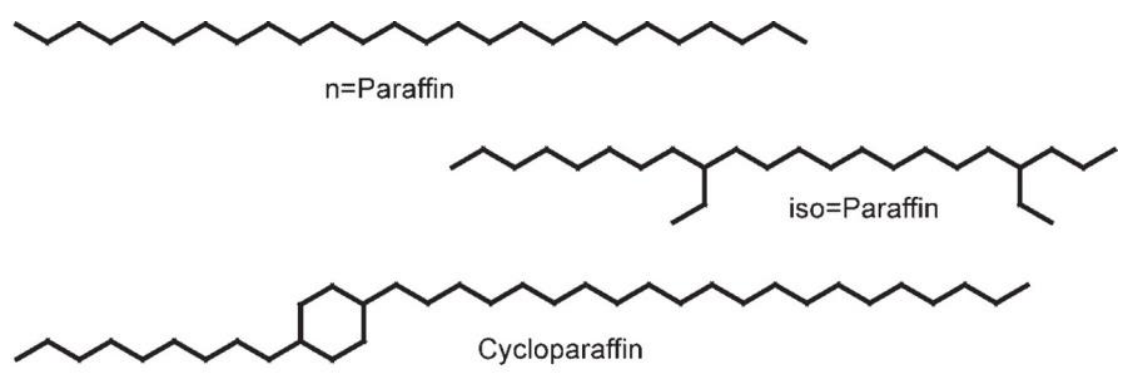

(c)

Fig. 1: Structure of (a) Bitumen; (b) Asphalten; and (c) Paraffin Wax.

reaction mechanisms.

In the present experimental study, a comparison of hydrocracking process mechanism based on two kinds of heavy hydrocarbon fractions will be provided. The first is the extract of natural asphalt (Buton Asphalt) represented aromatic hydrocarbon; and the second is waxy residue (bottom result of raw paraffinic oil refinery). The chemical structure of both materials is shown in fig. 1.

Hydrocracking process of asphalt and waxy residue is the reaction of heterogen catalytic. In heterogen system, reactant and catalyst are in different phase. Here the reactant and product are in liquid and gas phase respectively. The catalyst used in the process of hydrocracking is bifunctional heterogen catalyst containing two kinds of active cores from $\mathrm{H}-\mathrm{H}, \mathrm{C}-\mathrm{H}$ bond and $\mathrm{C}-\mathrm{C}$. Hydrocracking metal core is a metal mixture from Group VIII $(\mathrm{Co}, \mathrm{Ni})$ with group $\mathrm{VI}(\mathrm{Mo})$ in order to increase the hydrogenisastion reaction. Hydrocracking catalyst spesification depends on the feed which be processed and the required product. Usually for cracking of heavy fraction becoming gasoline, it needs hydrocracking catalyst with a high acid metal core, like $\mathrm{Ni}, \mathrm{Pd} / \mathrm{Al}_{2} \mathrm{O}_{3}-\mathrm{SiO}_{2}$.

Campbell I. A. and Christian P. C. (2012) reported that there are five significant stages to be occured during the process. Those are: 1) Reactant difusion or moving from stream phase to the active component of catalyst through catalyst pore structure; 2) Reactant chemisorption in the catalyst active component; 3) 
Chemical reaction of reactants to obtain the products, 4) Products desorption from catalyst active component; and 5) Products difusion or moving through catalyst pore structure to stream phase.

The reaction speed of asphalt hydrogenation is influenced by the partial pressure of hydrogen in linear ways (Sui et al., 2010). The consumed hydrogen during the process is only $10 \%$, therefore the partial pressure of hydrogen is considered constant. The reported result shows that the reaction in thermal/pirolysis cracking process is first order pseudo reaction (Balci et al., 1993). In general, the factors affect the hydrocracking reaction rate are space velocity, kind of catalyst, temperature and pressure. The relationship between constants of chemical reaction rate with temperature generally follows the Arrhenius equation: $k=A \cdot e^{-E / R T}$

The average activation energy of the hydrocarbon cracking process is between $10-15 \mathrm{kcal} / \mathrm{mol}$.

The catalytic hydrocracking reaction that being studied is operated in fixed bed reactor with several assumptions as follow:

- Along the reactor: there is no gradient consentration in radial way, temperature gradient in radial or axial way. Therefore the constant of reaction speed is considered constant in every spot along the reactor with reaction speed equation suitable to kinetic models proposed.

- Gradient pressure in reactor is considered small compared to the change of operational speed, so it is ignored.
- The reaction is operated at fixed bed reactor with very small catalyst size, therefore, the diffusion speed of reactant molecule and product is relatively big compared to the chemical reaction speed. Therefore, the reaction speed mechanism deciding the process is chemical reaction speed.

The differential equation describing the converted reaction and the reaction of speed can be written in Equation (2).

$d\left(X_{A}\right)=\frac{\left(-r_{A}\right)}{F_{A O}} d W$

\section{Kinetic Model}

The goal to make some reaction models of hydrocracking (model 1, 2, 3 and 4 ) is to predict the most suitable rate of reaction for optimum results of 4 reaction mechanisms models which are assumed. The optimum results are indicated from minimum SSE (sum square of error). The other goal is to obtain possible maximum conversion by variating some parameters existed in the equation, for example : increasing of pressure parameter will increased the conversion value, esc.

The real hydrocracking reaction is actually very complicated and complex, but in the model presented it is assumed that the hydrocracking reaction follows one order reaction toward asphalt vapor and one order toward hydrogen gas.

The process of asphalt hydrocracking follows the whole reaction as follow:
$\mathrm{A}+\mathrm{H}_{2} \Leftarrow \Rightarrow$ Gas
$\mathrm{A}+\mathrm{H}_{2} \Leftarrow$ Oil

In this case, reactant substance and result substance is in the form of gas, while the catalyst is solid. 
64 Experimental Study on Hydrocracking Process of Asbuton Hydrocarbon, Based on the Aromatic, and Waxy Residue, Based on Paraffinic, by using Pt/Pd Catalyst and $\mathrm{Y}$-Alumina in a Fixed Bed Reactor According to Fogler (2005), around 75\%
of all the mechanism of heterogen
reaction, surface reaction becomes a
limited reaction in comparison to the
adsorption or desorption.

De Pauw (1975) carried out a research of hydrocracking and isomerisation $n$ Pentane with pressured hydrogen using Platina/ Alumina catalysator. They showed that the hydrocracking reaction speed and isomerisation were controlled by the surface reaction $n$-pentane in $\mathrm{Al}_{2} \mathrm{O}_{3}$ than in adsorption $\mathrm{n}$-pentane in the catalyst surface.

Fogler (2005) showed that the mechanism and speed steps limited reaction between adsorbed toluena and $\mathrm{H}_{2}$ gas (Fogler, 2005). Based on the result of the similar researches, the models proposed in this research are assumed that the surface reaction is limit reaction.

There are the symbol reactions existing in the mechanism model with explanation : $A=$ asphalt extract or waxy residue, $\mathrm{H}=$ Hydrogen, $\mathrm{s}=$ catalyst solid, $\mathrm{Hs}=$ bond hydrogen in the surface, As= asphalt extract or waxy residue bond with catalyst solid, Gs = gas bond with catalyst solid, Ms= oil bond with catalyst solid, G= gas, and $M=$ oil. Furthermore, the preparation of the proposed model as follows:

\section{Model 1:}

Asphalt vapor and $\mathrm{H}_{2}$ gas are adsorbed in the catalyst surface, the adsorbtion of $\mathrm{H}_{2}$ is in the form of $\mathrm{Hs}$.

The mechanism of reaction is as follow:

$$
\begin{aligned}
& \mathrm{A}+\mathrm{s} \Leftarrow \Rightarrow \mathrm{As} \\
& \mathrm{H}_{2}+2 \mathrm{~s} \Leftarrow 2 \mathrm{Hs} \\
& \mathrm{As}+2 \mathrm{Hs} \Leftarrow \Rightarrow \mathrm{Gs}+2 \mathrm{~s} \\
& \mathrm{As}+2 \mathrm{Hs} \Leftrightarrow \mathrm{Ms}+2 \mathrm{~s}
\end{aligned}
$$

$$
\begin{aligned}
\mathrm{Gs} & \Leftrightarrow \mathrm{G}+\mathrm{s} \\
\mathrm{Ms} & \Leftrightarrow \mathrm{M}+\mathrm{s}
\end{aligned}
$$

Hydrocracking reaction is irreversible reaction, therefore

$$
\left(-r_{S}\right)_{G}=\frac{K_{S G} K^{\prime} P_{A} P_{H 2}}{\left(1+K_{A} P_{A}+K_{H 2}^{\prime} P_{H 2}^{0.5}+K_{G}^{\prime} P_{G}+K_{M}^{\prime} P_{M}\right)^{3}}
$$

In the same way as asphalt reaction into oil is as follows:

$$
\left(-r_{s}\right)_{M}=\frac{K_{S M} K^{\prime} P_{A} P_{H 2}}{\left(1+K_{A} P_{A}+K_{H 2}^{\prime} P_{H 2}^{0.5}+K_{G}^{\prime} P_{G}+K_{M}^{\prime} P_{M}\right)^{3}}
$$

\section{Model 2:}

A and $\mathrm{H}_{2}$ are adsorbed in the catalyst surface, the adsorption $\mathrm{H}_{2}$ is in the form of $\mathrm{H}_{2} \mathrm{~S}$. the reaction mechanism is as follow:

$$
\begin{aligned}
& \mathrm{A}+\mathrm{s} \Leftarrow \Rightarrow \mathrm{As} \\
& \mathrm{H}_{2}+2 \mathrm{~s} \Leftarrow \Rightarrow 2 \mathrm{Hs} \\
& \mathrm{As}+\mathrm{H}_{2} \mathrm{~s} \Leftarrow \Rightarrow \mathrm{Gs}+\mathrm{s} \\
& \mathrm{As}+\mathrm{H}_{2} \mathrm{~s} \Leftarrow \Rightarrow \mathrm{Ms}+\mathrm{s} \\
& \mathrm{Gs} \Leftarrow \mathrm{G}+\mathrm{s} \\
& \mathrm{Ms} \Leftarrow \Rightarrow \mathrm{M}+\mathrm{s}
\end{aligned}
$$

Hydrocracking reaction is irreversible reaction, therefore,

$$
\left(-r_{S}\right)_{G}=\frac{K_{S G} K^{\prime} P_{A} P_{H 2}}{\left(1+K_{A} P_{A}+K_{H 2}^{\prime} P_{H 2}^{0.5}+K_{G}^{\prime} P_{G}+K_{M}^{\prime} P_{M}\right)^{2}}
$$

It is similar to asphalt reaction becoming oil that obtains:

$$
\left(-r_{S}\right)_{M}=\frac{K_{S M} K^{\prime} P_{A} P_{H 2}}{\left(1+K_{A} P_{A}+K_{H 2}^{\prime} P_{H 2}^{0.5}+K_{G}^{\prime} P_{G}+K_{M}^{\prime} P_{M}\right)^{2}}
$$

\section{Model 3:}

The material adsorbed is only $A$, while $\mathrm{H}_{2}$ is not adsorbed in the catalyst surface. The mechanism of the reaction is as follow.

$$
\begin{aligned}
& A+\mathrm{s} \Leftarrow \Rightarrow A s \\
& A s+\mathrm{H}_{2} \Leftarrow \Rightarrow \mathrm{Gs} \\
& \mathrm{As}+\mathrm{H}_{2} \Leftarrow \Rightarrow \mathrm{Ms}
\end{aligned}
$$


$\mathrm{Gs} \Leftarrow \Rightarrow \mathrm{G}+\mathrm{s}$
$\mathrm{Ms} \Leftarrow \Rightarrow \mathrm{M}+\mathrm{s}$

Hydrocracking reaction is irreversible reaction, therefore:

$$
\left(-r_{S}\right)_{G}=\frac{K_{S G} K^{\prime} P_{A} P_{H 2}}{\left(1+K_{A} P_{A}+K_{G}^{\prime} P_{G}+K_{M}^{\prime} P_{M}\right)}
$$

It is similar to asphalt reaction becoming oil that obtain,

$$
\left(-r_{S}\right)_{M}=\frac{K_{S G} K^{\prime} P_{A} P_{H 2}}{\left(1+K_{A} P_{A}+K_{G}^{\prime} P_{G}+K_{M}^{\prime} P_{M}\right)}
$$

\section{Model 4:}

With power law model, speed equation of asphalt hydrocracking reaction is:

$$
\begin{aligned}
& \left(-r_{A 1}\right)=r_{S G}=k_{S G} \cdot P_{A \cdot}^{a} \cdot P^{b}{ }_{H 2} . \\
& \left(-r_{A 2}\right)=r_{S M}=k_{S M} \cdot P_{A \cdot}^{a} \cdot P^{b}{ }_{H 2} .
\end{aligned}
$$

From the explanation above, it can be assumed that:

1. Reaction occurring in hydrocracking process of asphalt and wax residue will produce liquid phase of hydrocarbon compound and gas phase light hydrocarbon.

2. Kinetic hydrocracking reaction of asphalt with Mo-Ni/ $Y$-Alumina catalyst and waxy residue with $\mathrm{Pt}-\mathrm{Pd}$ / zeolite promotor catalyst follows one kinetic model proposed, and the constant of reaction speed is suitable to Arrhenius Equation.

\section{Experimental Method}

The main materials are Buton asphalt extracted, waxy residue, hydrogen and various catalysts, such as $\gamma$-Alumina catalyst with metal promotor of Molibdenum Nickel (metal comparison $\mathrm{Mo} / \mathrm{Ni}=1 / 2$ with the weight $1 \%$ and density of $0.4056 \mathrm{gram} / \mathrm{cm}^{3}$ ) for hydrocracking of buton asphalt and $\mathrm{Pt} / \mathrm{Pd}$ catalyst with zeolite promotor (the comparison $\mathrm{Pt} / \mathrm{Pd}=2 / 1$ and density of $1.0528 \mathrm{~g} / \mathrm{cm}^{3}$ ) for hydrocracking of waxy residue. The physical properties of Buton asphalt extract and waxy residue can be seen in the Table 3.

Table 3. Properties of Buton Asphalt Extract and Waxy Residue

\begin{tabular}{lcc}
\hline \multicolumn{1}{c}{ Properties } & $\begin{array}{c}\text { Buton Asphalt } \\
\text { Extract }\end{array}$ & $\begin{array}{c}\text { Waxy } \\
\text { Residue }\end{array}$ \\
\hline SG $\left(60^{\circ} \mathrm{F}\right)$ & 1,013 & 0,9275 \\
\hline $\begin{array}{l}\text { Flash Point } \\
(\text { Cleveland }),{ }^{\circ} \mathrm{C}\end{array}$ & 120 & 220 \\
\hline Water Content & - & Trace \\
\hline $\begin{array}{l}\text { Penetration } \\
\text { Conradson } \\
\text { Carbon Residue } \\
\text { (CCR) }\end{array}$ & 92 & $\begin{array}{c}34,5 / 10 \\
\mathrm{~mm}\end{array}$ \\
\hline $\begin{array}{l}\text { Moleculer } \\
\text { Weight, } \\
\text { gram } / \mathrm{mol}\end{array}$ & - & $3,731 \%$ \\
\hline
\end{tabular}

The hydrocracking process of Buton asphalt extrat and waxy residue are carried out in a reactor unit made of stainless steel with diameter and height $4 \mathrm{~cm}$. An arrangement of the instrument is shown in Figure 2.

The reactor column was equipped with electric heater to control the reactor temperature. Reactor column was also equipped with sensory thermocopel wire to determine the reactor temperature. While as the feed heater, it is used autoclave with diameter $7.5 \mathrm{~cm}$ and height $24 \mathrm{~cm}$.

The result was obtained in the form of fraction of gas, liquid, and solid asphalt, the reaction residue inside the asphalt heater. Gas fraction coming out from the 


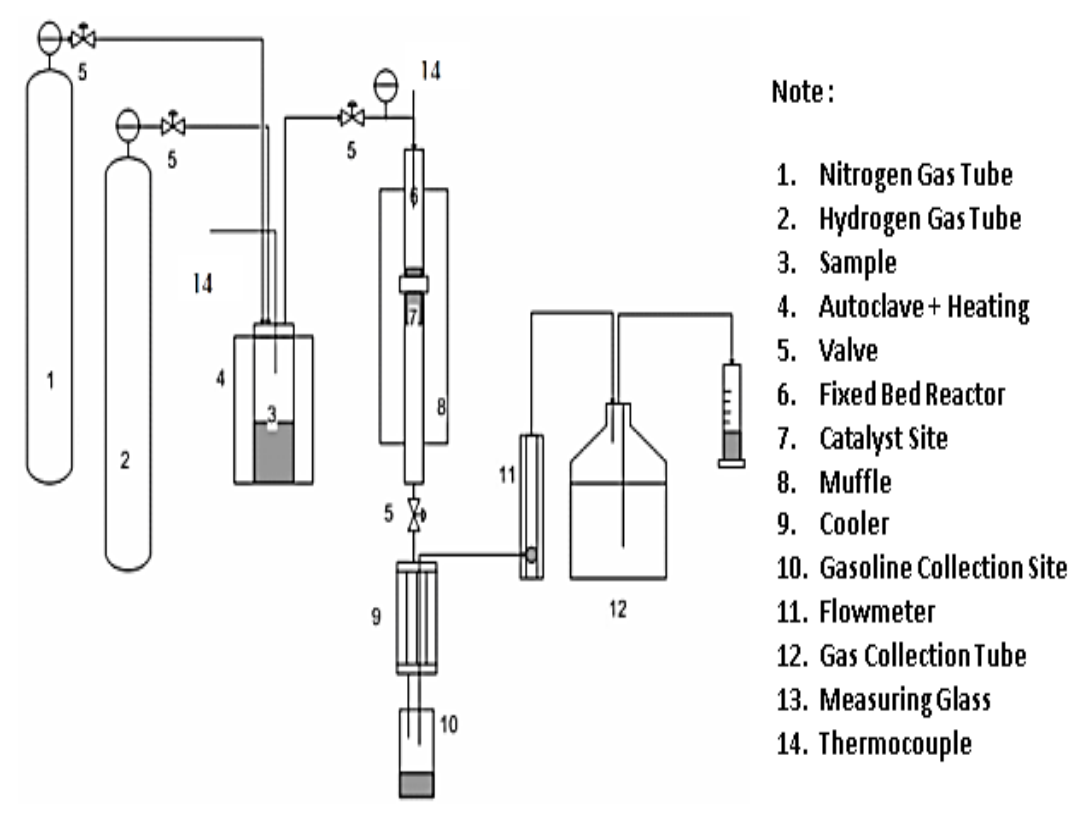

Fig. 2: Schematic diagram of the experimental apparatus

reactor became the mixture of Hydrogen $\left(\mathrm{H}_{2}\right)$ of reaction residue and reaction result. Here, the gas as the reaction result was estimated/calculated from mass balance.

The whole process occurred in semibatch process. Here the material was 30 grams heated in the autoclave in the approximately temperature $400^{\circ} \mathrm{C}$. In order to know the characteristics of the evaporation of asphalt in the autoclave, there was an experiment of heating without any catalyst with varied time of heating. Furthermore the relationship between the evaporated asphalt weight and the heating time is shown in Figure 3.

Based on the evaporation characteristic of asphalt in the autoclave, the condition likely to be constant was obtained in around 60 minutes reaction estimated in the $10^{\text {th }}$ minutes until $70^{\text {th }}$ minutes, in which material evaporation speed in that condition was almost constant, and the evaporated material during the time was considered to be able to represent the whole characteristic of the asphalt. By using this condition, it is expected that constant process assumption in the reactor was able to be close to reality.

Total asphalt Conversion $\left(x_{A}\right)$ during hydrocracking reaction was calculated by following those equation:

$X_{A}=\frac{W_{A O}-W_{A}}{W_{A O}}$

While, asphalt conversion becoming gas was:

$X_{G}=\frac{G}{W_{A O}}$

Asphalt Conversion becoming oil was:

$X_{M}=\frac{W_{M}}{W_{A O}}$

With, $X_{A}=X_{G}+X_{M}$

The most suitable model for hydrocracking reaction was determined by 
optimizing difference of constant reaction speed in line with the proposed model. Optimal value of this constants was done by using Hook Jeeves method. Asphalt conversion from the estimation result was calculated by using modified Euler method. Differential equation used to calculate asphalt conversion was:

$d X_{A} / d W=\left(-r_{A}\right) / F_{A O}$

where $\left(-r_{A}\right)$ is a function of the constant of reaction speed, $X_{A}, P$, and $T$.

\section{RESULT AND DISCUSSION}

The initial work in the present experiment was to determine the speed of gas flow (asbuton extract and waxy rsidue) on the basis of the heating time. Evaporated material composition in this condition was used as the standard composition of material feed before entering the reactor. From Figure 3, it can be obtained that gas speed of heated material was observed after 10 minute of the process.

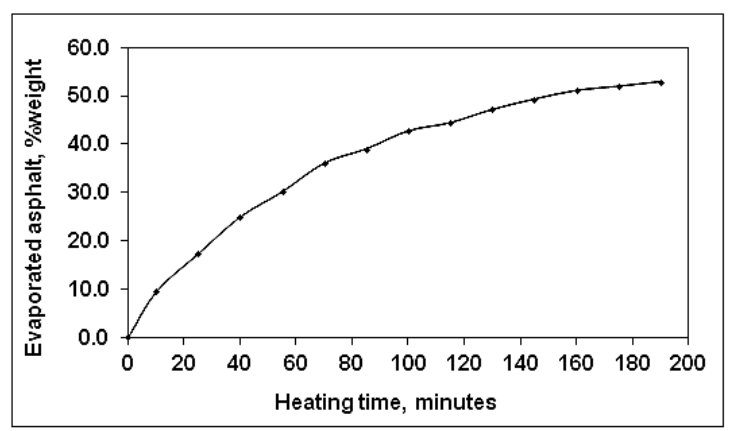

Fig.3: Relationship between \% Evaporated Asbuton Extract Weight and Heating Time.

Hydrocracking reaction was carried-out in abundant hydrogen condition, for saturing olefin and aromat compound, in order to avoid the formation of abundant carbon deposit in the catalyst. Oil content in the reaction was analyzed by using the gas chromatography (GC). Here the reaction was focused to maximize gasoline fraction as the result of main reaction. From the result of the study, the data are presented in the next sections.

\section{Temperature}

Reaction temperature influences convertion of hydrocracking reaction for three kinds of the materials. The experimental condition was under the pressure from 6 up to 14 bar and the increase of temperature for three materials (asbuton extract, waxy residue, catalyst Molibdenum-Nickel/Y-Alumia, or PT/PdZeolite). Probably the change of conversion by increasing temperature was caused by the rise of activation energy and reaction speed.

\section{Pressure}

Pressure also influences the convertion. It is shown by the rising conversion of processed three materials. In the temperature approximatelly $300^{\circ} \mathrm{C}$ until $500^{\circ} \mathrm{C}$, conversion tendency of the materials increased because the concentration in the form of vapor became more dense as shown in Figure 4.

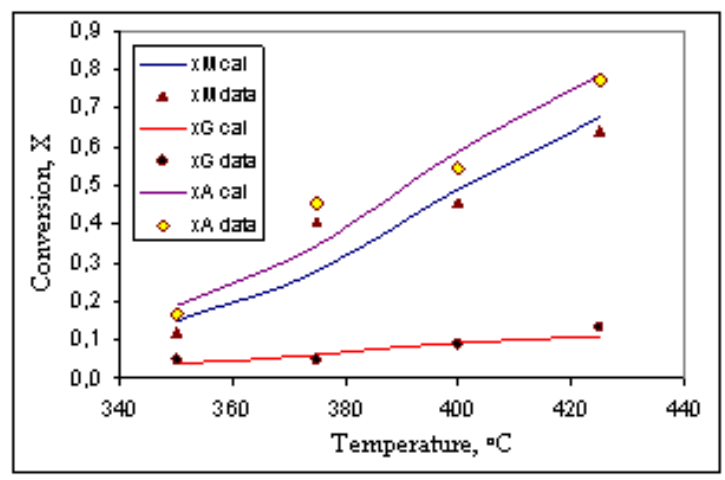

Fig. 4: Conversion Correlation and Temperature in Pressure 10 bars 
68 Experimental Study on Hydrocracking Process of Asbuton Hydrocarbon, Based on the Aromatic, and Waxy Residue, Based on Paraffinic, by using Pt/Pd Catalyst and $\mathrm{Y}$-Alumina in a Fixed Bed Reactor

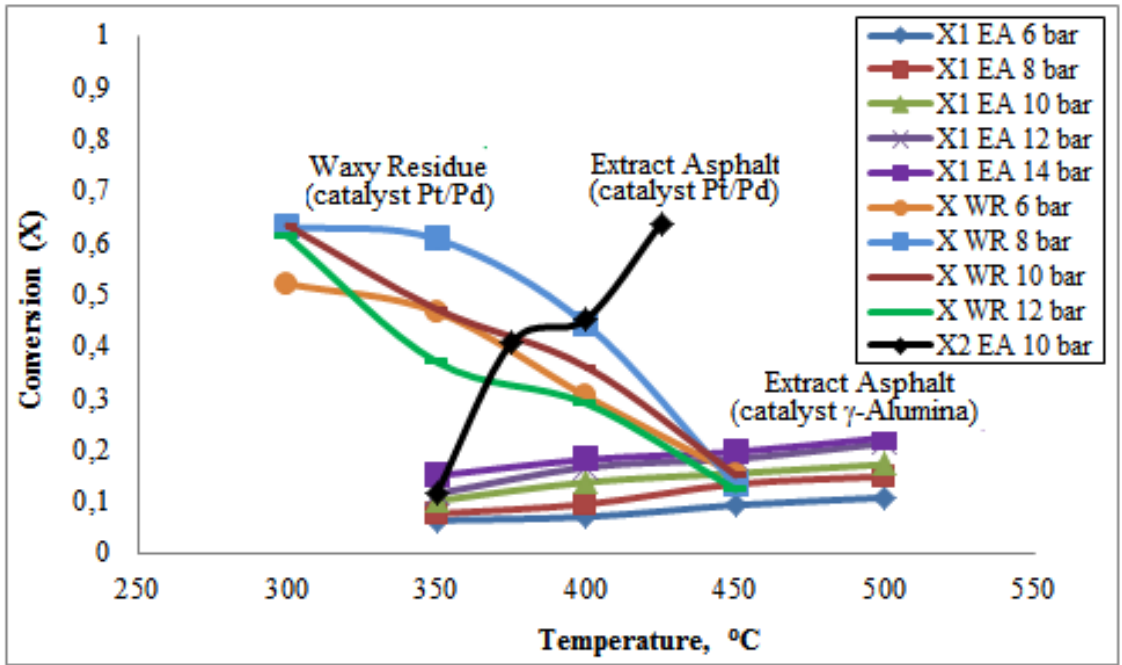

(a)

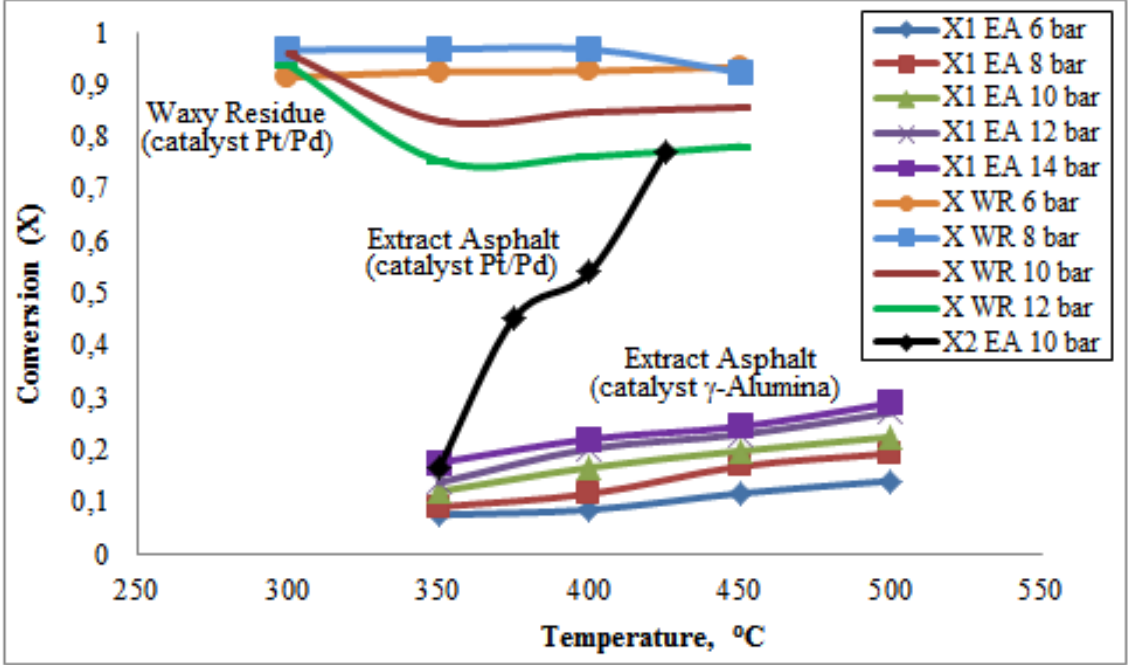

(b)

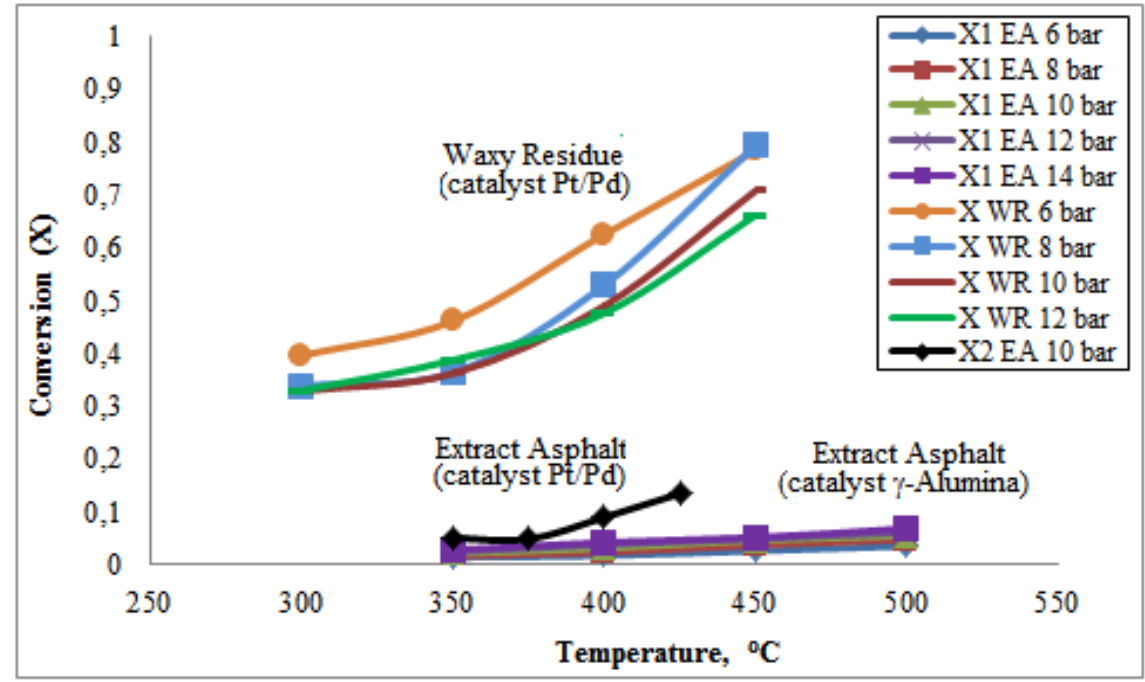

(c)

Fig. 5: (a) Conversion from gas product; (b) Conversion from oil product; and (c) Total conversion from gas and oil product. 


\section{Conversion}

In the present works, the reaction product consisted of liquid and gas. Total conversion was obtained from the number of the conversion of each liquid and gas product as shown in Figure 5.

\section{Catalyst}

In this research, two catalysts were used. Those are $\mathrm{Y}$-Alumina/Mo-Ni for asbuton extract and Pt-Pd/Zeolit for waxy residue and the other asbuton extracts. If it is analyzed from two kinds of asbuton using both two catalysts, it can be determined that asbuton kind with $\mathrm{Mo} / \mathrm{Ni}$ Y-Alumina catalyst resulted smaller conversion than $\mathrm{Pt} / \mathrm{Pd}$ catalyst. Both of the catalysts in asbuton extract after being analyzed and calculated by showing the smallest correction have the same model which is Model 3.

In the hydrocracking process of asbuton extract with $\mathrm{Pt} / \mathrm{Pd}$, it was used two kinds of catalysts with different composition. The first catalyst used $\mathrm{Pt} / \mathrm{Pd}$ with composition of 1:2 (much more than the Palladium metal), while the second catalyst used $\mathrm{Pt} / \mathrm{Pd}$ with the composition 2:1 (much more than the Platinum). The comparison between operational temperature with conversion becoming oil and gas to each catalyst can be seen in the Figure 6.

In the Figure 7, it can be seen that in operational temperature between 350$425^{\circ} \mathrm{C}$, catalyst 1 shows a better conversion result than catalyst 2 . This means that for the conversion of asphalt becoming oil, Palladium in $\mathrm{Pt} / \mathrm{Pd}$ catalyst involved better in determining reaction result.
On the other hand as shown in Figure 8, it can be seen that the trend of the asphalt conversion becoming gas in the catalyst 1 that was smaller than that of the catalyst 2 . This means also that the tendency of gas formation is dominated by the working quality from Platinum metal in the catalyst Pt/Pd.

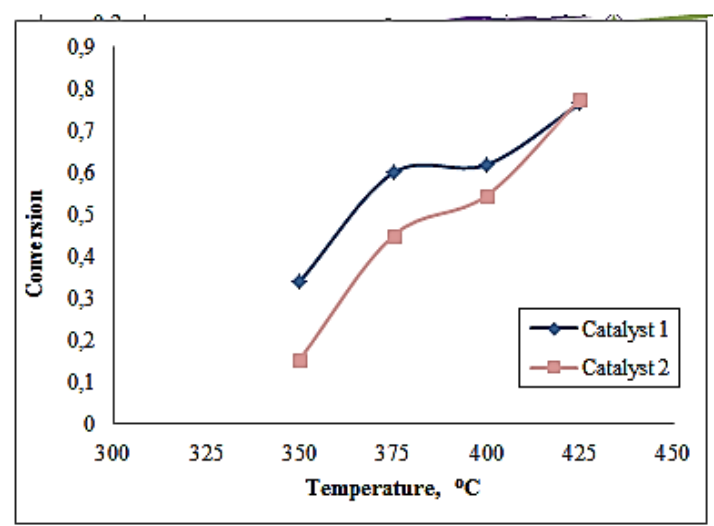

(a) Total Conversion BAE

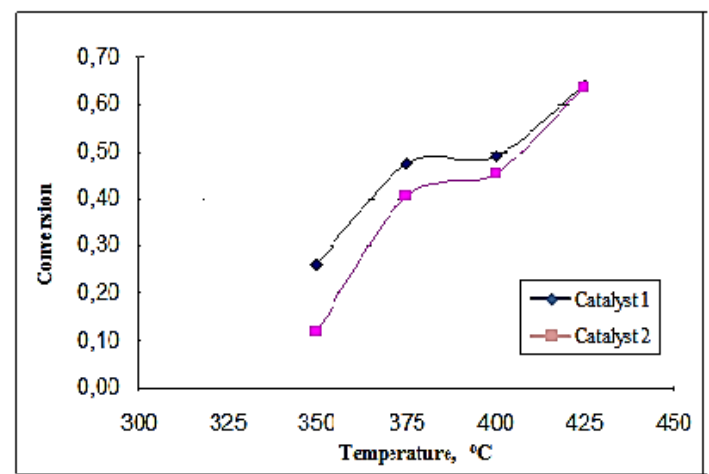

(b) Conversion BAE becoming Oil

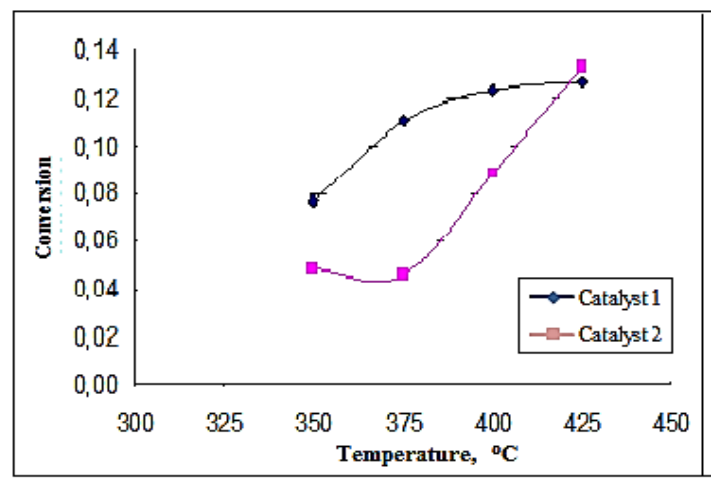

(c) Conversion BAE becoming Gas

Fig.6 : Conversion of BAE (10 bar Pressure) 
70 Experimental Study on Hydrocracking Process of Asbuton Hydrocarbon, Based on the Aromatic, and Waxy Residue, Based on Paraffinic, by using Pt/Pd Catalyst and -Alumina in a Fixed Bed Reactor

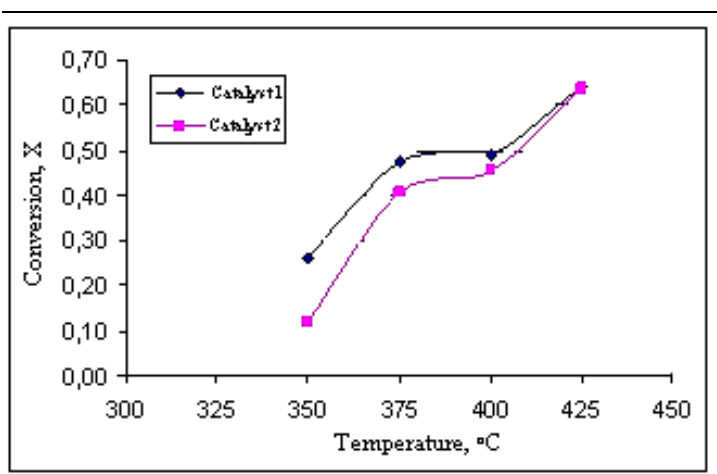

Fig. 7: Correlation Graph between Temperature with Conversion becoming Oil in $10 \mathrm{~atm}$ Pressure

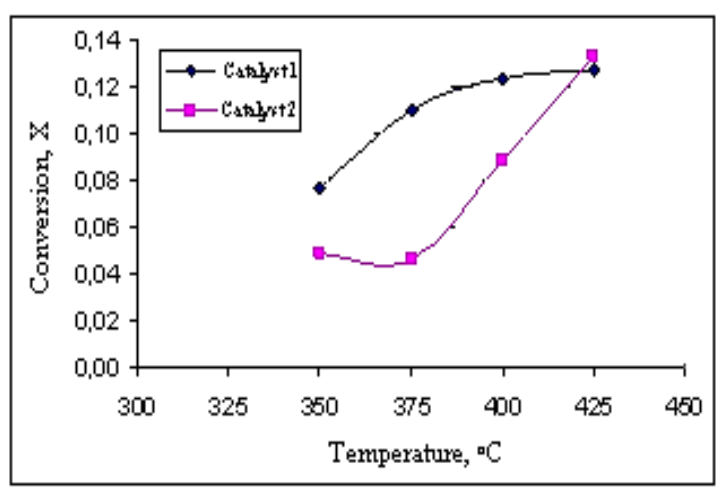

Fig. 8: Correlation Graph between Temperature and Conversion becoming Gas in 10 atm Pressure
Furthermore as shown in fig. 7 and 8 , under a higher temperatures (between $400^{\circ} \mathrm{C}$ and $425^{\circ} \mathrm{C}$ ) the conversions show the same results both in gas conversion and in oil conversion.

In the process of hydrocracking Buton Asphalt/Asbuton Ekstract (BAE) using catalyst Mo-Ni/ $Y$-Alumina and the pressure condition was until 14 bars, the conversion was low. The simulation used four models. If the operational pressure is increased, the tendency of hydrocracking conversion BAE will also increase. Under the pressure from 80 bar until 100 bar, Model 3 shows the conversion was really significant almost similar to $B A E$ conversion using the pressure of catalyst $\mathrm{Pt} / \mathrm{Pd}$ of 6 until 14 bar.

The calculation result of asphalt hydrocracking reaction using model formulation obtained and extra-polated in 160 bar pressure with the operational condition was close to field data that can be seen in fig 9.

In the next section the data for asphalt

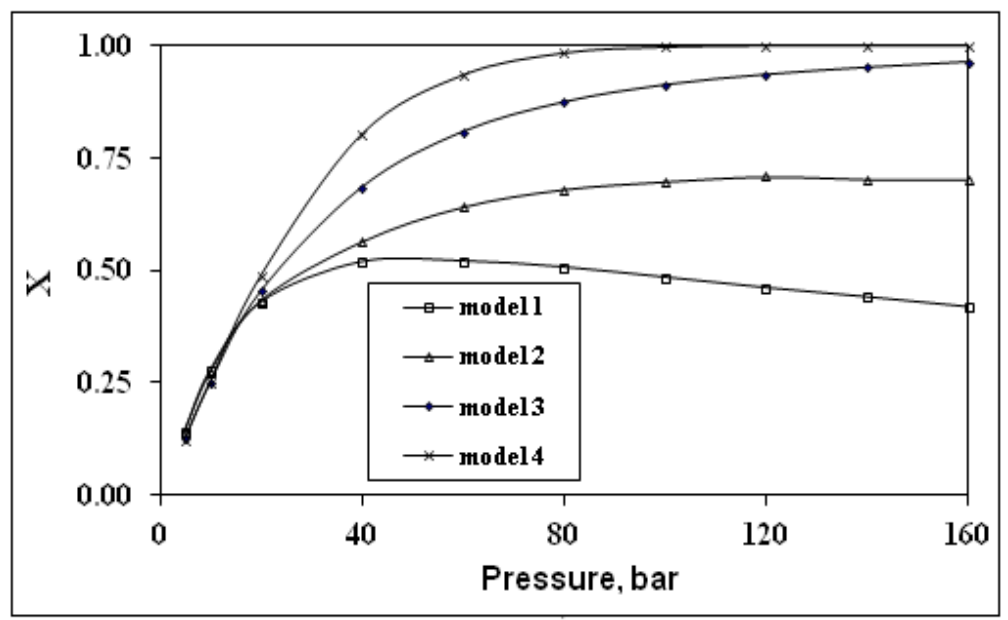

Fig. 9: Calculation Result of Extra-polation of Asphalt Conversion 
Table 4. Test Result of Activity Mo-Ni / $\gamma$-Alumina catalyst $\left(\mathrm{T}=400^{\circ} \mathrm{C}, \mathrm{P}=10 \mathrm{~atm}\right)$

\begin{tabular}{lccc}
\hline \multicolumn{1}{c}{ Catalyst } & $\begin{array}{c}\text { Liquid Result, } \\
\text { \% wt }\end{array}$ & $\begin{array}{c}\text { Gas Result, } \\
\text { \% wt }\end{array}$ & $\begin{array}{c}\text { Cocas \&Residue, } \\
\text { \%wt }\end{array}$ \\
\hline Without any catalyst & 20.49 & 28.63 & 50.88 \\
$\mathrm{Mo}_{1}-\mathrm{Ni}_{4} / \gamma-$ Alumina & 14.65 & 33.76 & 51.59 \\
$\mathrm{Mo}_{1}-\mathrm{Ni}_{4} / \mathrm{Nb}_{2} \mathrm{O}_{5}(6 \%)-\gamma-\mathrm{Al}$ & 13.57 & 34.49 & 51.94 \\
$\mathrm{Mo}_{1}-\mathrm{Ni}_{4} / \mathrm{Nb}_{2} \mathrm{O}_{5}(12 \%)-\gamma-\mathrm{Al}$ & 9.81 & 33.77 & 56.42 \\
\hline
\end{tabular}

Table 5. The comparison with another research

\begin{tabular}{|c|c|c|}
\hline Information & Fogler (2005) & Present Work \\
\hline - Materials & Toluene & Buton asphalt extract \\
\hline - Catalyst & silica alumina Crystal & Molibdenum-Nikel/ $\gamma$-alumia \\
\hline - Reactor & fixed bed & fixed bed \\
\hline - Temperature, ${ }^{\circ} \mathrm{C}$ & 600 & $350-500$ \\
\hline - Pressure & $1-20 \mathrm{~atm}$ & $6-14 \mathrm{bar}$ \\
\hline - Kinetic Model & $\begin{array}{l}\text { Surface reaction between adsorbed } \\
\text { toluene and hydrogen gas (not } \\
\text { adsorbed on the surface of the } \\
\text { catalyst) }\end{array}$ & $\begin{array}{l}\text { Surface reaction between adsorbed asphalt } \\
\text { gas and hydrogen gas (not adsorbed on } \\
\text { the surface of the catalyst) }\end{array}$ \\
\hline $\begin{array}{l}\text { - Constanta reaction speed, } \mathrm{k}_{\mathrm{s}} \\
\{\text { gram / (g catalyst. jam . } \\
\text { atm)\} }\end{array}$ & & $\begin{array}{l}\mathrm{k}_{\mathrm{SM}}=1.274 \mathrm{e}^{-1837,41 / \mathrm{T}} \text { or }=0.155\left(600^{\circ} \mathrm{C}\right) \\
\mathrm{k}_{\mathrm{SG}}=2.839 \mathrm{e}^{-3379,09 / \mathrm{T}} \text { or }=0.059\left(600^{\circ} \mathrm{C}\right)\end{array}$ \\
\hline - $\mathrm{K}_{\mathrm{T}}, \mathrm{K}_{\mathrm{A}}(1 / \mathrm{atm})$ & $0.004637\left(600^{\circ} \mathrm{C}\right)$ & $3.12 \mathrm{e}^{692,75 / \mathrm{T}}$ or $=6.899\left(600^{\circ} \mathrm{C}\right)$ \\
\hline - $\mathrm{K}_{B}, \mathrm{~K}_{\mathrm{M}}(1 / \mathrm{atm})$ & 1.01 (in temperature $600^{\circ} \mathrm{C}$ ) & $0.157 \mathrm{e}^{1048,7 / \mathrm{T}}$ or $=6.817\left(600^{\circ} \mathrm{C}\right)$ \\
\hline - $K_{G}(1 / a t m)$ & 1.26 (in temperature $600^{\circ} \mathrm{C}$ ) & $4.499 \mathrm{e}^{362,8 / \mathrm{T}}$ or $=0.522\left(600^{\circ} \mathrm{C}\right)$ \\
\hline
\end{tabular}

with catalyst Mo-Ni/ $/$-Alumina and $\mathrm{Pe}$ $\mathrm{Pd} /$ Zeolit in conversion process of hydrocracking in BAE will be discussed. Table 4 shows the comparison of hydrocracking conversion process with the catalyst Mo-Ni/ $\mathrm{Y}$-Alumina and Pt$\mathrm{Pd} /$ Zeolit. Here Sarifudin (2004) has conducted an experimental work on the influence of the ratio $\mathrm{Ni} / \mathrm{Mo}$ and the content $\mathrm{Nb}_{2} \mathrm{O}_{5}$ toward the character, activity, and selectivity of $\mathrm{Ni}-\mathrm{Mo} / \mathrm{Nb}_{2} \mathrm{O}_{5}-\gamma$ $\mathrm{Al}_{2} \mathrm{O}_{3}$ catalyst and modifies it to the cracking process of aspalten fraction from Buton asphalt. In the present experiment, the activity test of the catalyst was conducted under the temperature of $400^{\circ} \mathrm{C}$ and a pressure of $10 \mathrm{~atm}$. The result of catalyst activity Mo-Ni / $\gamma$-Alumina can be seen in Table 4.

The other work from Fogler (2005) for kinetic model of hydrocracking reaction of more simple hydrocarbon compound that belongs to one kind, which is hydrocracking reaction of toluene compound with hydrogen gas obtaining benzene and methane in fixed bed reactor with silica alumina crystal catalyst in reaction temperature $600^{\circ} \mathrm{C}$ as follow:

$$
\begin{aligned}
& \mathrm{C}_{6} \mathrm{H}_{5} \mathrm{CH}_{3}+\mathrm{H}_{2} \longrightarrow \mathrm{C}_{6} \mathrm{H}_{6}+\mathrm{CH}_{4} \\
& \left(-r_{T}\right)=\frac{1.4 \times 10^{-8} P_{H 2} P_{T}}{\left(1+1.01 P_{T}+1.26 P_{B}\right)}
\end{aligned}
$$


72 Experimental Study on Hydrocracking Process of Asbuton Hydrocarbon, Based on the Aromatic, and Waxy Residue, Based on Paraffinic, by using Pt/Pd Catalyst and $\mathrm{y}$-Alumina in a Fixed Bed Reactor

Table 6. Kinetic Model Comparison obtained by this Experiment

\begin{tabular}{|c|c|c|c|}
\hline No. & Parameter & Asbuton Extract (BAE) & Waxy Residue \\
\hline 1. & Materials & Asbuton Extract & Waxy residue \\
\hline 2. & Catalyst & $\begin{array}{l}\gamma \text {-Alumina with } \\
\text { promotorNi/Mo }\end{array}$ & $\mathrm{Pt} / \mathrm{Pd}$ with promotor Zeolit \\
\hline 3. & $\begin{array}{l}\text { Evaporation Time of } \\
\text { Materials }\end{array}$ & 190 minutes & 120 minutes \\
\hline 4. & Temperature & $350-500{ }^{\circ} \mathrm{C}$ & $300-450^{\circ} \mathrm{C}$ \\
\hline 5. & Pressure & $6-14$ bar & $6-12$ bar \\
\hline 6. & Reaction Mechanism & $\begin{array}{l}\text { Model } 3 \text { (only asbuton vapor } \\
\text { adsorbed on the catalyst } \\
\text { surface. } \mathrm{H}_{2} \text { was not adsorbed). }\end{array}$ & $\begin{array}{l}\text { Model } 1 \text { (Waxy residue vapor and } \\
\text { hydrogen gas adsorbed on the } \\
\text { catalyst surface. Hydrogen was } \\
\text { adsorbed in the form of } \mathrm{Hs} \text { ). }\end{array}$ \\
\hline
\end{tabular}

7. The Equation of Kinetic Reaction:

Model 1 (for waxy residue) :

$$
\left(-r_{s}\right)_{M}=\frac{K_{S M} K^{\prime} P_{A} P_{H 2}}{\left(1+K_{A} P_{A}+K_{H 2}^{\prime} P_{H 2}^{0.5}+K_{G}^{\prime} P_{G}+K_{M}^{\prime} P_{M}\right)^{3}}
$$

Model 3 (for buton asphalt) :

$$
\left(-r_{S}\right)_{M}=\frac{K_{S G} K^{\prime} P_{A} P_{H 2}}{\left(1+K_{A} P_{A}+K_{G}^{\prime} P_{G}+K_{M}^{\prime} P_{M}\right)}
$$

Where $\mathrm{k}_{\mathrm{s}}=1.4 \times 10^{-8} \mathrm{~mol}$ toluene $/ \mathrm{g}$ catalyst.s.atm), $\mathrm{K}_{\mathrm{T}}=1.01 / \mathrm{atm}$, and $\mathrm{K}_{\mathrm{B}}=$ 1.26/atm.

The comparison between the present research result and Fogler (2005) can be seen completely in Table 5 .

Table 5 shows that the constant reaction speed of this research result was bigger than that of the result by Fogler (2005). This shows that Molibdenum$\mathrm{Nikel} / \gamma$-alumina catalyst wich was used in this reserach has a bigger activeness than that of the catalyst of silica alumina crystal. Molibdenum-Nikel/ $\gamma$-alumina catalyst was bifunctional heterogeneous catalyst containing two kinds of active cores, which are $\mathrm{Mo}-\mathrm{Ni}$ and acid core $\mathrm{Al}_{2} \mathrm{O}_{3}$.

\section{CONCLUSION}

From the obtained result during the present research, it can be concluded as follow:
1. Asphalt hydrocracking reaction using catalyst Molibdenum-Nikel/ $\gamma$-alumina and PT-Pd/zeolit produced gas fraction and oil fraction of hydrocarbon compound. The reaction speed increases with the increase of temperature and pressure in the reaction.

2. Conversion of asphalt hydrocracking reaction using catalyst MolibdenumNikel/ $\gamma$-alumina was lower than that of catalyst Pt/Pd under the same temperature and pressure. The conversion increases to be similar to the reaction of the catalyst $\mathrm{Pt} / \mathrm{Pd}$ if the pressure was increased becoming more than 100 bars.

3. Buton asphalt hydrocracking reaction in fixed bed reaction using catalyst Molibdenum-Nikel/ $\gamma$-alumina became surface reaction between adsorbed asphalt vapor with hydrogen gas that 
was not adsorbed on the surface of the catalyst.

4. The constants value of reaction speed was influenced by temperature and it followed Arhenius equation.

5. Kinetics equations of asphalt hydrocracking reaction becoming oil and gas are as follow:

(a) Asphalt hydrocracking reaction becoming oil

$\left(-r_{S}\right)_{M}=\frac{\left\{1.274 e^{-1837.41 / T}\right\} 3.12 e^{692.75 / T} P_{A} P_{H 2}}{\left(1+3.12 e^{692.75 / T}+0.157 e^{1048.7 / T}+4.499 e^{362.8 / T} \cdot P_{M}\right)}$

with the error $4.121 \%$.

(b) Asphalt hydrocracking reaction becoming gas

$\left(-r_{S}\right)_{G}=\frac{\left\{2.839 e^{-3379.09 / T}\right\} 3.12 e^{692.75 / T} P_{A} P_{H 2}}{\left(1+3.12 e^{692.75 / T} P_{A}+0.157 e^{1048.7 / T}+4.499 e^{362.8 / T} \cdot P_{M}\right)}$

With the error 5,221\%.

\section{NOMENCLATURE}

A : Arrhenius constant

E : Activation energy, (cal/gmol)

$A E \quad$ : Asbuton Extract

$F_{A o}:$ feed flow rate of raw material gas in the reactor, ( gram wax / hour)

$k_{a}:$ constant of the adsorption rate of raw material onto the catalyst surface

$k_{G} \quad: \quad$ constant of the desorption rate of raw material from the catalyst surface

$k_{H 2}$ : constant of the adsorption rate of hydrogen gas onto the catalyst surface
$k_{M} \quad: \quad$ constant of the desorption rate of product from the catalyst surface

$k_{S A}:$ constant of the reaction rate of raw material to gasoline and gas onto the catalyst surface

$k_{S M} \quad:$ the constant of the reaction rate of raw material to gasoline onto the catalyst surface

$k_{S G}:$ the constant of the reaction rate of raw material to gas onto the catalyst surface

$K_{A} \quad$ : the equilibrium constant of the adsorption rate of raw material onto the catalyst surface

$K_{H 2}$ : the equilibrium constant of the adsorption rate of hydrogen gas onto the catalyst surface

$K_{G} \quad$ : the equilibrium constant of the desorption rate of gas product from the catalyst surface

$K_{M} \quad$ : the equilibrium constant of the desorption rate of gasoline product from the catalyst surface

$P_{A} \quad$ : the partial pressure of waxy gas in phase gas, atm

$P_{G} \quad$ : the partial pressure of gas product in phase gas, atm

$P_{H 2}$ : the partial pressure of hydrogen gas, atm

$P_{M} \quad$ : the partial pressure of gasoline gas in phase gas, atm

$-r_{A}$ : the adsorption rate of raw material onto catalyst surface, ( gram of wax reacted / hour / 
74 Experimental Study on Hydrocracking Process of Asbuton Hydrocarbon, Based on the Aromatic, and Waxy Residue, Based on Paraffinic, by using Pt/Pd Catalyst and Y-Alumina in a Fixed Bed Reactor

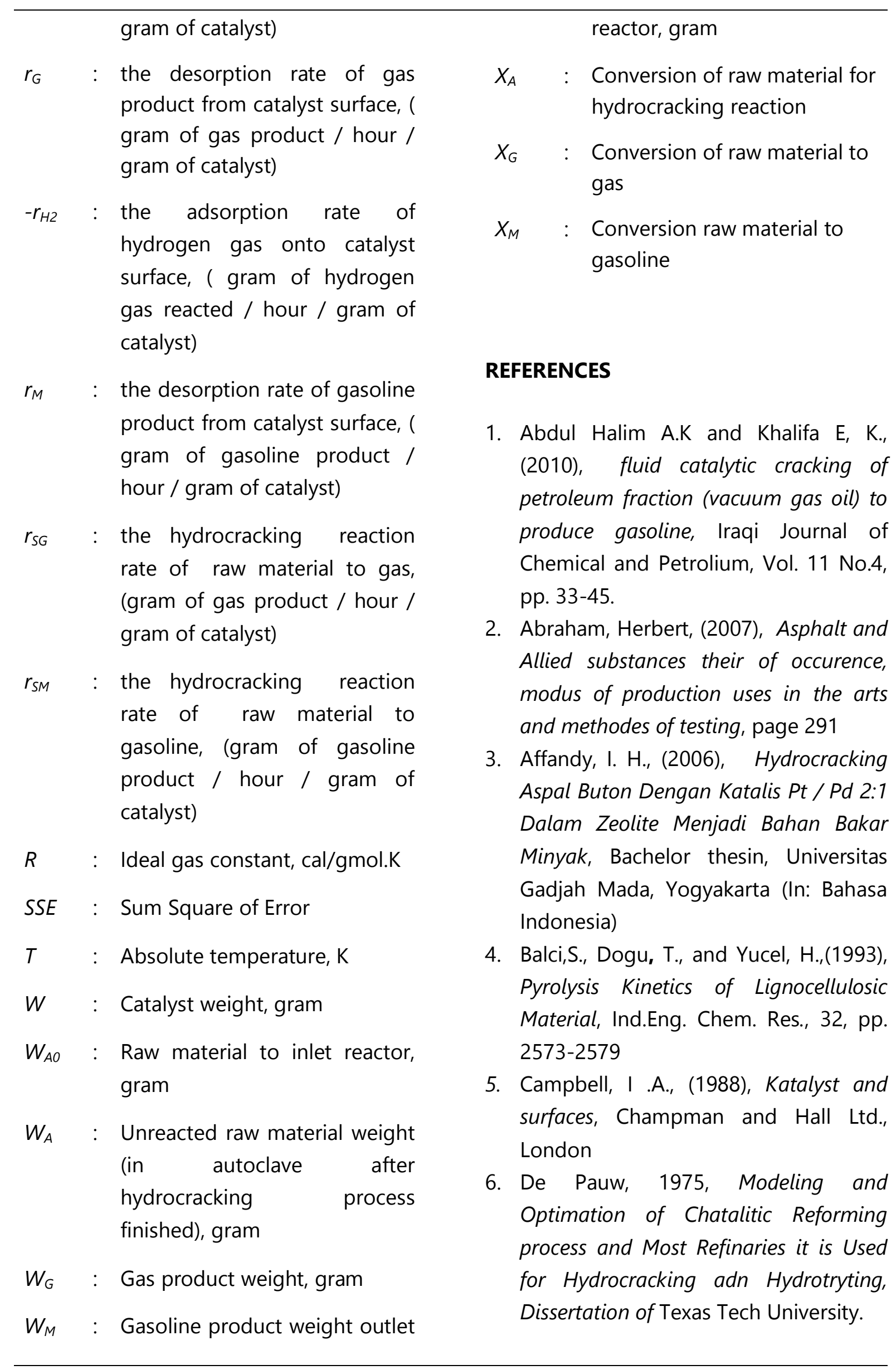


7. Fogler,H.S., (2005), Elements of Chemical Reaction Engineering, 4th Edition, pp. 241-310, , Prentice-Hall International, Inc., New Jersey.

8. Hatch,L.F., and Matars, S., (2000), From Hydrocarbons to Petrochemicals", second edition, pp. 24-40, Gulf Publishing Company, Houston.

9. Shui, H., Chen, Z., Wan, Z., Zhang, D., 2010. Kinetics of Shenhua coal liquefaction catalyzed by $\mathrm{SO} 4 / \mathrm{ZrO}_{2}$ solid acid, FUEL, Vol. 89, issue 1, pp. 67-72. In Univesity of Northumbria at Newcastle.

10. Jones, D.S.J., (1995), Elements of Petroleum Processing, pp. 275-278, John Willey \& Sons, New York.

11. Bhutani, N., Ray, A.K., and Angaiah, G.P. (2006), Modeling, Simulation, and Multi-objective Optimization of an Industrial Hydrocracking Unit, Ind. Eng. Chem. Res., Vol. 45 (4), pp 1354-1372.
12. Sarifudin,K., (2004), PengaruhRasio $\mathrm{Ni} / \mathrm{Mo}$ dan Kandungan $\mathrm{Nb}_{2} \mathrm{O}_{5}$ terhadap Karakter, Aktivitas dan Selektivitas Katalis $\mathrm{Ni}-\mathrm{Mo} / \mathrm{Nb}_{2} \mathrm{O}_{5}-\gamma-\mathrm{Al}_{2} \mathrm{O}_{3}$ dan Modifikasinya untuk Proses Perengkahan Fraksi Aspalten dari Aspal Buton", Master Tesis, Program Pasca Sarjana UGM, Yogyakarta (In: Bahasa Indonesia).

13. Speight, J.G., (2014), The Chemistry and Technology of Petroleum, vol 3, Fifth edition, pp 189-315, CRC Press.

14. Suryo P. and Murachman B., (2012), Teknologi Minyak Bumi, pp.146-150, Pasca Sarjana Universitas Gadjah Mada , Yogyakarta (In: Bahasa Indonesia).

15. Widayati, A., 2003, Rattan Cane Harvesting in Lambusango Forest, Buton, Indonesia : A Sustainable Practice or a Threat to Forest Conversation, Disertation 